\title{
BASIC STUDIES OF THE RESTORATION OF SOUND CONDUCTING SYSTEM BY TYMPANOPLASTY
}

\author{
By \\ Y. OKUNO

\begin{abstract}
From the Department of Oto-Rhino-Laryngology Okayama University Medical School (Director: Prof. S. Takahara)
\end{abstract}

Part 1. On the Conduction Capacity of the Columella

\begin{abstract}
After extracting the temporal bone of cats the author gave sound stimuli to this temporal bone through the external auditory canal and measured the vibration amplitude of the labyrinthine side by means of a capacitative probe and determined the conduction capacity of the sound conducting system at $250,500,1,000$ and 2,000 cps when the lever function of the ossicular chain is obliterated. The results are as follows :
\end{abstract}

1. When the malleus and incus are removed from the normal sound conducting system, the sound conduction capactiy decreases about $28 \mathrm{db}$ in average.

2. After the removal of the malleus and incus from the normal sound conducting system:

a) When the portion between the capitulum of the stapes and the part of the tympanic membrane corresponding to the short process, is communicated with an artificial columella, the sound conduction capacity increases abont $21 \mathrm{db}$ as compared with that in the item 1 , and shows a decrease in the capacity by $7 \mathrm{db}$ in average as compared with the normal.

b) When the central part of the tympanic membrane and the capitulum of the stapes are communicated with an artificial columella, the sound conduction capacity increases $16 \mathrm{db}$ in average as compared with that of the iteml.

c) when the part of the tympanic membrane corresponding to the umbo and the capitulum of the stapes are communicated with an artificial columella, there can be observed an increase in the sound conduction capacity by about $14 \mathrm{db}$ as compared with that of the item 1, showing a decrease of about $14 \mathrm{db}$ as compared with the normal.

d) When the skin graft is placed on the capitulum of the stapes as to touch each other in the case where the tympanic membrane was deliberately removed, the sound conduction capacity decreases about $10 \mathrm{db}$ in average as compared with the normal.

3. The weight ratio of the artificial columellas used in the model experiments is $1: 3: 5$, and it seems that the lighter is the weight of the columella the better the restoration of the sound conduction.

4. It has been found that in the application of artificial columella the decrease in the sound conduction capacity is more marked in the high tone range than in the low tone range.

Part 2. Sound Conduction Capacity in Various Sound Conducting Systems by Manipulation

With the temporal bone removed from human sudjects, sound stimuli were given through the external auditory canal, and the vibration amplitude of the labyrinthine side was measured with a capacitative probe in order to estimate the efficacy of various sound pathways reconstructed by tympanoplasty. The following are the results:

1. When the antrum is blocked, the sound conduction capacity is raised by about $5 \mathrm{db}$ in the 
range below 1,000 cps, and is decreased by about $5 \mathrm{db}$ in the range of 2,000 cps.

2. In the attic, when there is an adhesion between the skin graft on onehand, the head of malleus and the incus on the other, the sound conduction capacity is diminished and it is especially marked in the range above $1,000 \mathrm{cps}$,

3. In order to maintain a better sound conduction capacity after tympanoplasty, it is desirable to leave a bony bridge and/or a vertical bony bridge to prevent the skin graft from adhesion.

4. When the long process of the incus and the stapes are connected with a polyethylene tube after separating the incudostapedial joint, the decrease in sound conduction capacity proves to be only about $2 \mathrm{db}$ in average.

\section{鼓室成形術の伝音系修復に関する基礎的研究}

\section{第 1 篇 Columella の伝音能力について}

岡山大学医学部耳楀咽喉科教室（主任：高原聯夫教授）

$$
\text { 大学院学生 奥 野 保 夫 }
$$

目次

1. 粕言

2. 実嗵方法

(1) 実験対象

(2) 実験装監

(3) 実験方法

3. 実“験成績

4. 総括及び考按

5. 結 語

\section{1. 緒 言}

塏室成形術は主に感音系の正常な慢性中耳炎に対し， 慢性炎症の病巣を完全に清掃して炎症を消鳃せしめ，且 つ破壊されている伝音機搆を再建して聴力の改善を図る といら二つの目的を有しているが，この二つの目的を遂 行するためには，各々の間に利害の相反する点が多いた め，鼓室成形術を成功に導びくためには種々の困難が克 服されなけれぱならない，しかし聴力改善の原理は，卵 円空にか、る音圧をできるだけ大にし，正円空にからる 音圧をできるだけ小にするという点にあるい。こつで卵 円空にからる音压の問題をとりあげて見ると，正常伝音 系の場合は競膜之鐙骨板の面積比及び耳小骨連鎖の植杆 比によつて卵円管にかるる音圧を大にする役揢が果され 2)，前者によつて Békésy によれば 17 倍に 3)，Wever and Lawrence に上机ば14 倍に 2)，後者は Dahmann によつて1.3侸に增強されるとされている。
しかし踣室成形術を行なつて，伝音系を修復した場

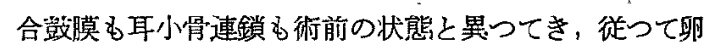
円空への音圧增強の様式も变つてくる.そこで㩆室成形 術で修復された新伝音系が幾許の伝音能力を有するかに ついて興味を持ち，多数の伝音采修復法のうち Wullstein の基本型の Type $\mathbb{I}^{5}$ ) 即ち myringostapediopexy 6) あるいは columella effect ${ }^{1)}$ 之呼ばれる形のるのに つて，その伝音能力の測定を試みた。

Myringostapediopexy は，桘骨及び砧骨を除去して 靕膜を直接鐙骨々頭にあてるもので，耳小骨連鎖による 植杆作用は失なわれているが，正常伝音系の場合の卵円 空への音王增強作用において果す役割から見れば，耳小 骨連鎖の消失に上る伝音能力の損失は予想以上に少ない と見られるワので，この点に特に興味を抱いた。

\section{2. 実験方法}

(1) 実跧対象

実験対象には中耳伝音器に異常の認められない成熟し た猫の剔出側頭骨を用い，これの襞膜から鐙骨板迄の伝 音系を利用した，即ちこれは猫の側頭骨を剔出した後， これに附着する軟部組織を除去し，エンヂンバーを使用 して錐体部を削つて内耳を除云し，鐙骨板周辺の骨を破 損しないように注意し乍ら卵円空を内耳側から露出せし めて鐙骨板が明視下にあるようにし，更に中耳骨胞を開 放して耳小骨連鎖及び㜔膜に操作を加えらる状態にした わのである。 
（2）垁験装置

実験装置は block diagram として第1 図に示し，こ のら方自作の微小静電溶量測定器の配線図を第 2 図に示 す23).

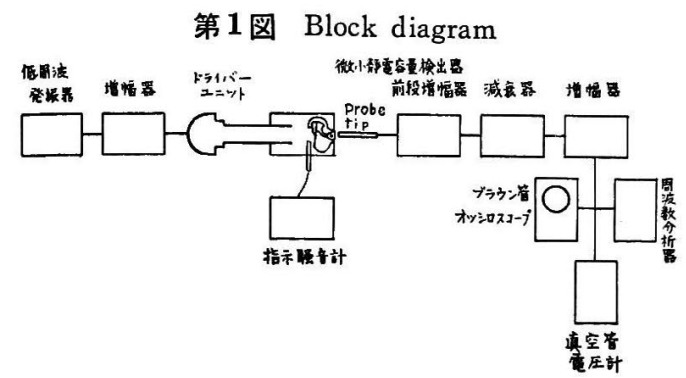

第 2 図微小静電容量变化检出器配線図

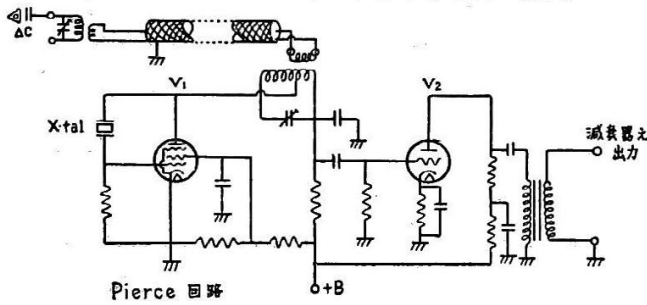

(3) 実験方法

実験は防音室内の shield room で行ない, 更に厚さ 約 $3 \mathrm{~cm}$ のフェルト上に実駼装置を置いて行なつた.

第 1 図に示すように，低周波発振器で発振した音波を 增幅器及び driver unit で堷幅する. 発振周波数は 250 cps, $500 \mathrm{cps}, 1000 \mathrm{cps}, 2000 \mathrm{cps}$, 及び $4000 \mathrm{cps}$ である.

剔出側頭骨は上下二つの block に分離できる重さ約 $2 \mathrm{~kg}$ の粘土中に埋没し，鐙骨板だけが露出するようにす る(第3图).

\section{第 3 図}

1)

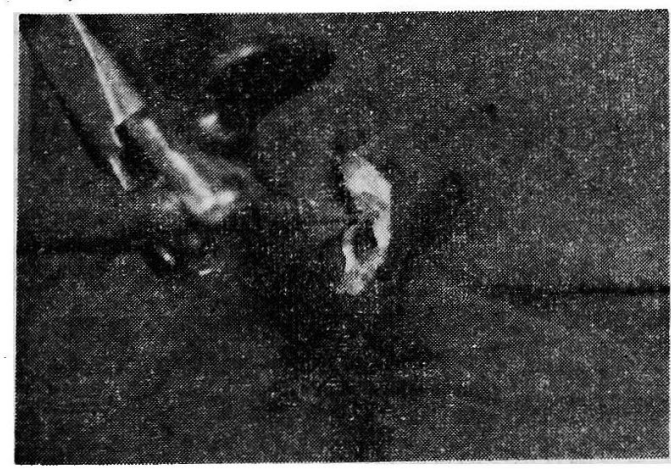

2)

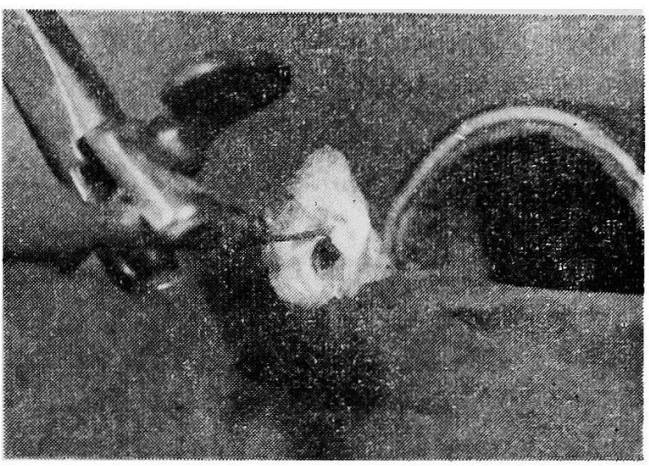

3)

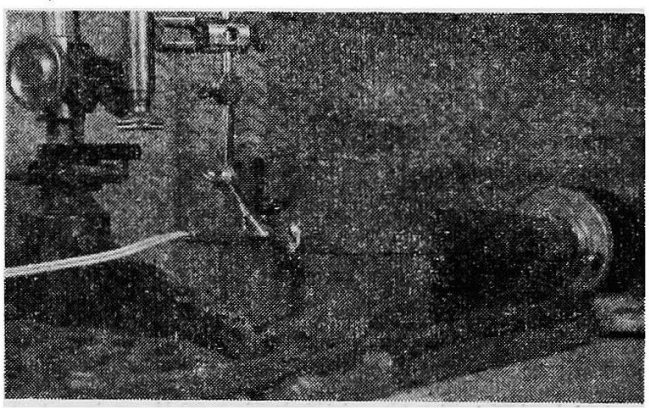

4)

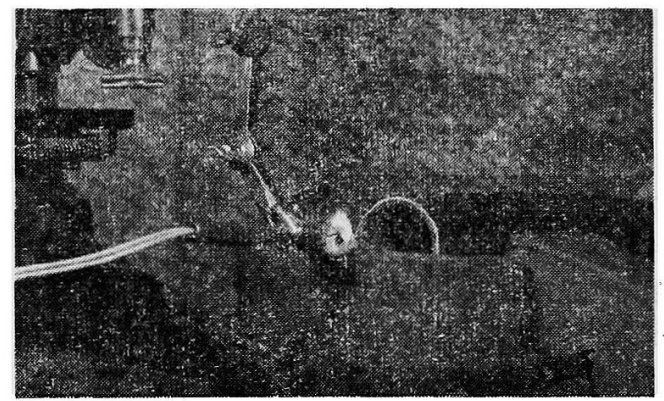

この剔出側頭骨の鼓膜の部に, driver unit からの音 波を太さ $5 \mathrm{~cm}$ 長さ $30 \mathrm{~cm}$ のゴム管で導びく、增幅器 及び driver unit で增幅された音波の音圧は，指示驧 音計により齱膜前面で測定したが，各周波数共 70 乃至 120phon であつた.

このよらにして，音波を与えた時の鐙骨板の振動を微 小静電溶量測定法で 検出する9）のであるが，使用した 微小電容量測定器の probe tip は倬径約 $1 \mathrm{~mm}$ で, こ れの先端と鐙骨板とが約 $0.5 \mathrm{~mm}$ の距離を保つように probe tip を固定した 3 ，剔出側頭骨を上下に分離でき 
る粘土塊に埋没したのは，笑験中剔出側副骨の伝音器に 操作を加える場合にも probe tip 之鐙骨板の間の位置 関係に変化をきたす事のないよらにするためであって， 上部の粘土塊をとり外せば剔出側頭骨の伝音器は明視下 にあり，側頭骨を動かす事なく伝音器への操作が可能で あつた.

実験に際しては，先ず正常伝音系の剔出側頭骨に，“前 述の各周波数とついて各種音圧で音刺战を与光，その㭙 の鐙骨板の振幅を微小静電容量変化測定器で検出してブ ラウン管オッシロスコープで観察し，又真空管電圧計が 一定の電圧を示すように減衰器を調節してこれを $\mathrm{db}$ 単 位で記録した。

次に伝音系に対し，後に述べるような㩆室成形術時の 操作を加えて新伝音系を作製しこれに各種の音刺战を 与えた時の鐙骨板の振幅を同様にして観察，記録し，正 常伝音系の場合と比較した。

伝音系の伝音能力の表現方法としては，同一の刺戟音 に対して鐙骨板の振幅が大きい伝音系が伝音能力が大で あると仮定し，例えば，1000cps で正常伝音系の鐙骨板 が振動してある一定の反応電圧を得るに要する刺㦸音圧 が 80dbで，又操作を加えた伀音系の鐙骨板が振動して 同じ区応電生を得た時の刺皒音圧が $90 \mathrm{db}$ で西つたとす ると，操作を加えた伝音系は正常伝音系と此較すると， $1000 \mathrm{cps}$ に和いて $10 \mathrm{db}$ の伝音能力の損失があるものと 見なした。

剔出側頭骨は，噟敗及び乾燥による变化を防ぐため に，生理的食塩水 $40 \mathrm{cc}$ に刘しマーゾニン液 $10 \mathrm{cc}$ を加 点大溶液に浸して承室に保存したが 8)，2 週間保存後に

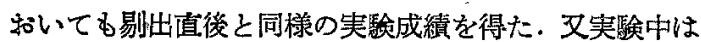
側頭骨周囲に上記溶液を含ませた綿を置いて乾燥を防い た。

\section{3. 実験成績}

刺战音は $250 \mathrm{cps}, 500 \mathrm{cps}, 1000 \mathrm{cps} 2000 \mathrm{cps}$ 及び 4000 cps の周波数を使用して湘定を試みたが，4000cps では 有意の值を得る事はできなかつた。

正常伝音系につ、て側定した所，その伝音能力は 250 cps, 500 cps, $1000 \mathrm{cps}$ 及び $2000 \mathrm{cps}$ については周波数 特性を示さなかつた。

次に操作を加えた伝音系の測定成績を操作を加えた順 そ述べる.

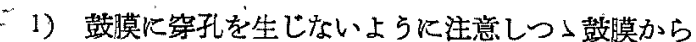

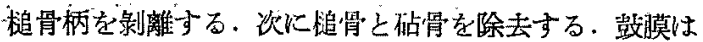
正常の揚合の円錐形の形を失ない, 随骨柄の部がや子薄
A

第 4 図

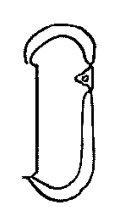

\section{B}

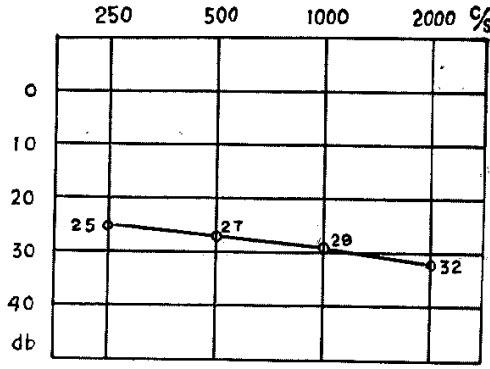

、平坦な膜となる（第4図 A).

この場合の伝音能力の撌失を，正常伝音系の伝音損失 を Odb としてオージオグラムに示すと第 4 図 B の如く で. 平均約 $28 \mathrm{db}$ の損失となる.

2) 竹を削つて直径約 $0.5 \mathrm{~m}$ の細い棒を作りこれを むつて 1）の伝音系に対してその橭膜と鐙骨々頭との間 に連絡を作つた. 竹製の columella の両端はセメダイ ンを使用して接着した。

1 鐙骨《頭と豉膜の桘骨柄先端附着部即ち umbo に相当与る部分（猫の場合偏心的な位置となる）を人工 columella で連絡した場合(第 5 図 A).

Columella の長さは $0.7 \mathrm{~cm}$ 重量は約 $5 \mathrm{mg}$ で, 䇅膜 となす角度は約 30 度であつた。
A

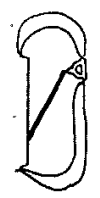

B

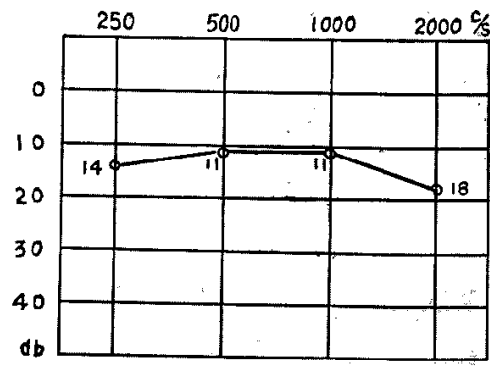

この伝音系の伝音能力の損失を正常伝音系の伝音損失 を Odb としてオーヂオグラムで示すと第 5 図 B の如く で，平均約 $14 \mathrm{db}$ の損失となる.

口鐙骨々頭と鼓膜中心部を人工 columella で連嵞 した場合（第6図 A).

Columella の長さは約 $0.5 \mathrm{~cm}$, 重量は約 $3.5 \mathrm{mg}$ で裁 膜となす角度は約 60 度であつた。

この伝音系の伝音能力の損失を，正常伝音系の伝音能 
A

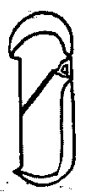

第 6 図

\section{B}

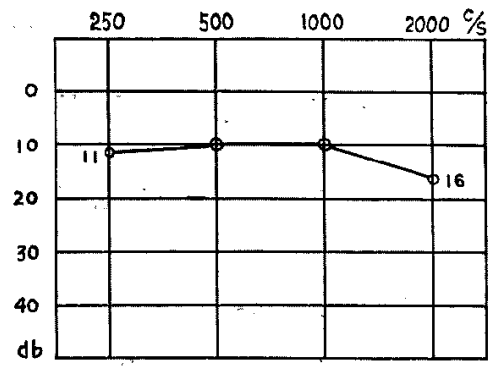

力の損失を Odb としてオーヂオグラムで示すと，第6 図 B の如くで平均約 12cb の損失となる.

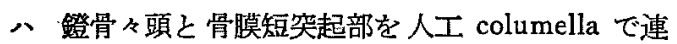
絡した場合（第7 图 A).

Columella の長さは約 $0.2 \mathrm{~cm}$, 重量は約 $1.5 \mathrm{mg}$, 碚膜 となす角度は約 80 度であつた。

この伝音系の伝音能力の損失を, 正常伝音系の伝音能 力の損失を $\mathrm{Odb}$ としてオーヂオグラムで示すと，第 7 図 B の如くで平均約 $7 \mathrm{db}$ の損失となる.

第 7 図

A

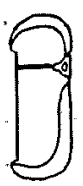

$A$

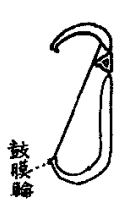

B

第 8 図

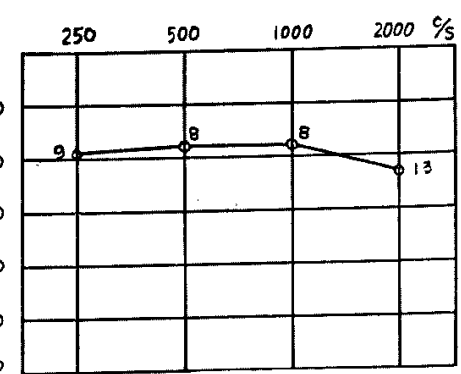

3）更に敨膜を子除去し，鐙骨々頭に人の大眼部から

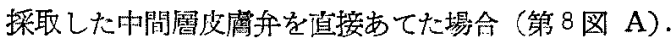

使用した皮腐手は，除去した颜膜の面皘の約 1.5 倍で， 及皮手江刘する鐙骨々頭の位置は偏心的であつた。

この場合の伝音能力は，正常伝音系の伝音能力の損失 を Odb としてオーヂオグラムで示すと第8図 B の如 くで平均約 10db の損失である.

皮属弁は，その辺縁にビオゲラチンを使用して鼓膜輪 及び上閔室内側骨壁々糊着させ，成可く皮弁が平坦で，

祭張を有するように試み心。

以上の実験成綘を小括すると，

（1）槌骨と砧骨を除去した伝音系では，約 $28 \mathrm{db} \cdot の$ 伝音損失がある。

（2）搥骨と砧骨を除去した伝音系の鼓膜と鐙骨々頭 を速絡するのに，直径約 $0.5 \mathrm{~mm}$ の竹を用いた.この columella があると伝音能力はかなりよくなるが, columella が鼓膜に附着する位直によつて差が見られ，豉膜 の短突起部之鐙骨々頭を連絡したものが最も伝音能力が

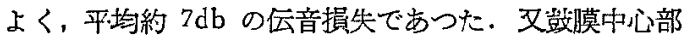
々鐙骨を連路したものではその伝音能力は平均約 $12 \mathrm{db}$ の損失で，鼓㮠の umbo の部分々鐙骨々頭を連絡した ものでは約 $14 \mathrm{db}$ の損失であつた。

（3）鐙骨に，人の皮鹰弁を直接張つたるのでは約 10 $\mathrm{db}$ の伝音損失が見られた。

\section{4. 䋓括及び考按}

振動体の観察, 測定方法には, 電気的あるいは光学 的な種々の方法があるが8) 13)，振動による静電容量の 变化を測定して振動体の振幅を湘定する方法は1941 年 Békésy ${ }^{3)}$ が耳小骨連鎖の振幅の剆定に用いている。こ の方法は鐙骨板の場合のように测定対象が小さい場合に 法特に都合がよい、15)。乙かし測定器の probe tip そ測定 の対象との距離が变ると湘定值に变化をきたすからろ， この実験で用いたように上下に分離でさる粘土塊に埋没 し固定して，側頭骨に一連の操作を加えても probe tip と敛骨板の間の位置関係が変らないようにすると，湘定 値の比較が簡単で便利である。

叉この実験では各伝音系で鐙骨板が同一振幅を示すに 要する刺此音圧を求めて伝音系の伝音能力を求める力法 をとつたので，鐙骨板の振幅の絶対量は測定しなからた。

及剔出側顽骨が 畭燥すると伝音能力の但下をきたす が，Békésy 剔出を速やが行ない，但温で湿度の高

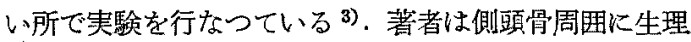
的食塩水を含ませた綿を置いて側頭骨をその綿と共に粘 


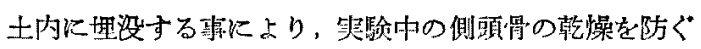
事ができた。

実験対象として選んだ猫の剔出側頭骨では战叒室小筋の 作用がないが，この点について切替は9音響性垡室小

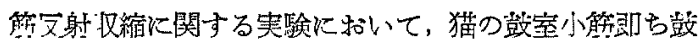

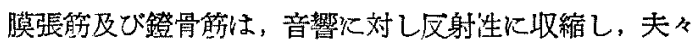
嫴膜及び鐙骨頭仁作用して伝音を抑制する作用があり， 特に鐙骨筋で著明であるが刺战音が 65phon 以下の場合 にはこのような豉室小筋の作用はあらわれない事を報告 している，従つて鼓室小能は 65 phon 以上の刺㦸音の場 合に作用するものと溚えると，実用德力の範田の音纴で は鼓室小筋は作用していないと考克てよいから，剔出側 頭骨飞鼓室小笳の作用がないといら問題は考虑しなくて るよいと仅定した。

一般に中耳の 音壬变換作用は，噋膜と 鐙骨板の 面積 比，耳小骨連績つ槓杆作用及び影膜による正円空への音 压の遮蔽効果から成立つていると考えられている2．こ れから推定すると前述した実駼に括いて，操作を加兄た

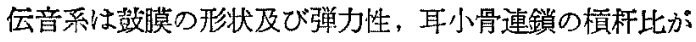
正常伝音系と異るが，もし操作を加光大伝音系における 鼓膜の形状及び弾力性の変化が 無視できるるのすすれ ば，操作を加えた伝音系と正常伝音系の間の伝音能力の 差は，耳小骨連鎖の槙杆作用によつて生じた差と見なす 事ができる。

Wever and Lawrence によれば 2)，1000cpsに括け る猫の耳小骨連鎖の槓杆作用は的 2.5 倍である．從つて $\boldsymbol{\alpha}=20 \log 2.5 \div 8 \mathrm{db}$

これは実験 2) の八，即ち鼓膜短突起部と鐙骨々頭を 連絡した場合の $1000 \mathrm{cps}$ に括ける伝音能力の損失の平 均值 $6 \mathrm{db}$ ，及び実験 3) で鐙骨々頭K，固有唼膜約 1.5 倍大の人の皮䖉升学張つた時の 1000 cps 《和ける伝音 能力の損失の平均値 $8 \mathrm{db}$ 見る時, 前者は理諭值に非 常に近く，後者では一致している。

乙かし恩地は 10)，中耳の 咅王变換比は鼓膜之鐙骨板 の面皘比及び耳小骨連鎖の他に，踥膜と槌骨柄間の弾 力, 砧鐙関節靬帯の弾力, 鼓膜及び棺砧体を一塊として のインピーダンス，蝸牛豰のインピーダンス等の要因に よるとしているから、これらの实験に和ける正常伝音系 との伝音能力の差が直ちに耳小骨連鎖の槙杆比の欠除代 原因するものと考克る事はできないが，桘骨及び砧骨を 除去した後，哣膜と鐙骨を人工 columella で連絡した 伝音系では最む能率の上いるので平均約 $7 \mathrm{db}$ ，鐙骨に直 接皮弁を張つたもので平均約 $10 \mathrm{db}$ の伝音損失に止まつ

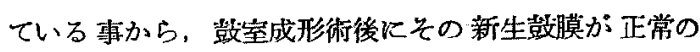
部膜と同様の有效振動面皘を有する場合を考学ると， myrimgostapediopexy に执いてもかなりよい術後聴力 を得る事が期待できる.

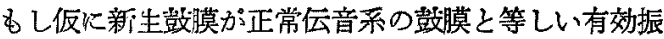
動面積を有するならば, myringo-stapediopexy の如く 樌杆比が 1 倍でるその聴力損失は，Schmitt 11) の理論 式

$$
\alpha=20 \log \frac{22}{22 \mathrm{~F}-\mathrm{d}}
$$

あるいは丸丸, 土田 ${ }^{12)}$ の理論式

$$
\alpha=20 \log \frac{43}{43 \times \mathrm{F}-\mathrm{di}+\mathrm{k}}
$$

のいずれによつて計算しても，3db 以内の聴力損失に止 まる筈であるが， myringestapediopexy の聴力が成功 例炕いて子殆儿ぞ 10 乃至 $15 \mathrm{db}$ 程度の聴力損失に止 まるのは (b) 7) 18)，この手術型に批る部生裁膜に問題 があるのであろらと考方られる。

従つて myringostapediopexy を行なら当つては, いかにして伝音に有利な新生鼓膜を作製するかという問 題の解決が空をれる。

次に㟝膜と鐙骨々頭の間を，值径約 $0.5 \mathrm{~mm}$ に削つた 竹で速絡した時，この columella を㩆獏に附着せしめ た位置により伝音能力に差が見られたが，この差が何の 要素によつてくるものかを知るために，次のような簡単 な模型実駼を行なつた。

先ず䜾膜に相当するものとして面径 $4 \mathrm{~cm}$ の浅い筒型 の金属枠に，薄いゴム膜を張り成可く一様な緊張を持た せる様にした。鐙骨には些物の約 5 倍大の鐙骨模型をレ シンで作製して用いた。

膜面が上下及び前後に移動できるようにした支持台に 金属枠を固定し，鐙骨は鐙骨板の前端及び後端をゴム紐

第 9 図

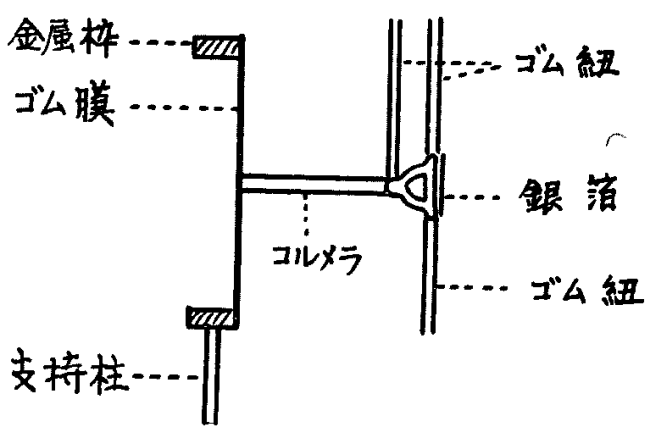


で举引し，更に鐙骨々頭の部もゴム紐で軽く率引して支 持した (第9図).

そして種々の重さ及び長さの棒をレジンで作製しこれ を columella とした.

これ等の模型を使用して, columella の重量, 長さ及 び䛠膜面となす角度による伝音能力の差を梌討した。

膜面と columella との角度は分度器によつて測定し， 鐙骨板の振動に前述の微小静電容量測定器を用いて湘定 した. 使用周没数は $500 \mathrm{cps}$ のみである。

測定成縝第 1 表《示す.

第1表 重量，膜面となす角度及び辰さの罢な つた columellaによる伝音能力の模型 実験による测定值

\begin{tabular}{|c|c|c|c|c|c|c|}
\hline \multirow{3}{*}{ No. } & \multirow{3}{*}{$\begin{array}{l}\text { 重量 } \\
\text { の比 }\end{array}$} & \multirow{3}{*}{$\begin{array}{l}\text { 膜 面 } 2 \\
\text { 小す角度 }\end{array}$} & \multirow{3}{*}{ 長さの比 } & \multirow{3}{*}{$\begin{array}{l}\text { 鐙骨板と } \\
\text { 膜の間の } \\
\text { 距離の比 }\end{array}$} & \multicolumn{2}{|c|}{ 伝音能力の搷失 } \\
\hline & & & & & \multicolumn{2}{|c|}{$\begin{array}{l}\text { 膜に対する col- } \\
\text { um. の位曍 }\end{array}$} \\
\hline & & & & & 中 心 & 偏 心 \\
\hline 1 & 1 & $90^{\circ}$ & 1 & 1 & $\mathrm{Odb}$ & $O d b$ \\
\hline 2 & 1 & $60^{\circ}$ & 1.7 & 1 & 1 & 1 \\
\hline 3 & 1 & $30^{\circ}$ & 2 & 1 & 2 & 2 \\
\hline 4 & 3 & $90^{\circ}$ & 1 & 1 & 4 & 4 \\
\hline 5 & 3 & $60^{\circ}$ & 1.7 & 1 & 4 & 5 \\
\hline 6 & 3 & $30^{\circ}$ & 2 & 1 & 6 & 6 \\
\hline 7 & 3 & $90^{\circ}$ & 2 & 2 & 10 & 10 \\
\hline 8 & 5 & 900 & 1 & 1 & 6 & 6 \\
\hline 9 & 5 & $60^{\circ}$ & 1.7 & 1 & 6 & 6 \\
\hline 10 & 5 & $30^{\circ}$ & 2 & 1 & 8 & 8 \\
\hline 11 & 5 & $90^{\circ}$ & 2 & 2 & 14 & 15 \\
\hline
\end{tabular}

この成續から推定すると, columella の豉膜との附着 位置を変えた際に夫ょ伝音能力に差を生じた原因は， 主として columella の重量及び陪膜面となす 角度の差 にあるのであろうと考えられ， columella の長さ及び columella の鼓膜への附盖位置そのるの（中心かあるい は㾫心か) にはあまり関倸がないのではないかと考光ら れる。

僦室成形術は，慢性中耳炎が手術対象であり，その病 変の程度が千差万別であるため，その伝音系修復に当つ ては，淮者によつて夫々の工夫がこらされるク14。 そ の5らの一つの方法として，伯骨及び砧骨が消失して おり，鐙骨々頭も破淕されているような場合，鐙骨に polyethlene tube あるいは tantarum wire 匴を附着 して columella を作る力法》があるが，以上の結果を あてはめて見ると，使用する columella は成可〈軽い ものが伝音能力を良好にする点からは有利であるうと推 定される.

页操作を加党た伝音系では $2000 \mathrm{cps}$ に招いて他の周 波数上りもかなり著明な伝音能力の但下が見られ，mass curve ${ }^{16)}$ に似た形を示すが，これは耳小骨速鎖を支持 していた靬带及び鼓室小筋の作用をするものが 3) 17)， columella には欠除し鐙骨にからる質量が增加したつめ に mass curve をとつたものではないかと推定される。

\section{5. 結語}

猫の剔出側頭骨に対し，音刺战を与兄た時の鐙骨板の 浱幅を微小静電容量测定器で測定する事によつて, 種々 の伝音系の伝音能力を測定し次の結論を得た。

1) 正常伝音系から船骨之砧骨堂除去すると，平均約 $28 \mathrm{db}$ の伝音能力の損失があつた。

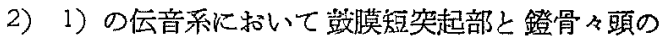
閒伦竹（㨁径 $0.5 \mathrm{~mm}$, 重量 $1.5 \mathrm{mg}$ ，長さ $2 \mathrm{~mm}$ ) で速絡 を作ると，平均約 7db の伝音能力の損失があつた。

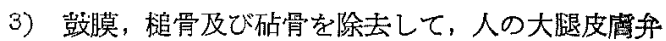
(部膜面皘の約 1.5 倍の面樍の中間層皮茾)で鐙骨を覆う 上，列均約 $10 \mathrm{db}$ の伝音能力損失があつた。

4）2）及び 3) の成績から，猫の耳小骨速鎖の梖杆 作用のみによる伝音能力の利得は約 $\varepsilon \mathrm{db}$ 前後に止まる と推定される。

5）1）の伝音系に対し，彭膜中心部之鐙骨々頭を竹 （咱径 $0.5 \mathrm{~mm}$, 重量 $3.5 \mathrm{mg}$, 長さ $5 \mathrm{~mm}$ ) で速絡すると, 平均約 $12 \mathrm{db}$ の伝音損失があつた。

6）1）の伝音系に対し，鼓膜の umbo の部之鐙骨々 頭とを竹（直径 $0.5 \mathrm{~mm}$, 重量 $5 \mathrm{mg}$, 長さ $7 \mathrm{~mm}$ ) で速 絡すると，平均約 $14 \mathrm{db}$ の伝音能力の提失があつた.

7）2，5）及び 6) の伝音系の間化 伝音能力の差を 生じた原因は模型実験の成績から推定すると，主にcolumella の重量及び踣膜面となす角度によってきたので あるらと考えられた。

8） 2)，3，5) 及び 6) の伀音系では 2000cps 飞お いて他の低音部周波数に和けるよりも著明な伝音能力の 低下が見られたが，これは mass curveをとつたもの と考完られた。 
第 2 篇 諸種伝音系の伝音能力について

1. 緒 言

2. 実験方法亚びに実験成絯

(1) 夷験対象

(2) 奏験装圆

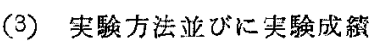

3. 総括及び考掉

4. 結

\section{1. 緒 言}

致室成形術を行なつてその目的を達し，術後聴力改善 を見ても，時日の経過と共に教室内に愿着性の変化をき たして，一旦上司した聴力が次第に悪化してくる例が ある ${ }^{18)}$. これの対策の一つとして, Zöllner ${ }^{1)}$ は所謂 Brücke を保存する事が得策であるとし，この Brücke を保存する目的は，この部の粘膜を保存して，症痕形成 による所の砧骨の運動䠋碍を最少限に止める点にあると されている19).

この考えを一歩進め，積極的に Brücke を作嘎し， その機能を高度にしたものとして，諸家720)の述べて いる control hole, 更に大内等 21$) の$ meatoplastische Methode と呼んでいる方法がある。これは vertikale Brücke と仮称するものを，外耳道後壁及びアヂッス側 壁を幅広く残して作り，これをるつて植皮弁を支持する ものである。

こにおいて，Brücke の有舆の鼓室成形術後の伝音 系の伝音能力に及ぼす影響について検討を加える目的 で，主に meatoplastishe Methode によつて vertikale Brückeを作製して鼓室成形術を行つた場合と，Brücke を捈去して桘骨，砧骨と植皮弁との間に契験的に瘉普性 変化を生ぜしめた場合の伝音系の伝音能力を比较し，更 に伝音能力に関する 2,3 の問題についても検討を加兄て 見た。

\section{2. 実験方法並び実験成績}

(1) 実験対象

既往に耳疾患がなく，中耳伝音器に病変を認めない人 の剔出側頭骨を使用した。

（2）実唡 装置

第1篇に述べた実駿装置を使用した。

(3) 実験方法並びに実験成縝

人の剔出側頭骨に対し，第 1 篇で奏験に使用した猫の

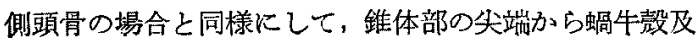

び三半規官を削つて行き，内耳側から卵円空を露出して 鐙吾板を明視下に置く。

次に踥室成形術の 形式で，外耳道皮膚を充分に 㓭離 し，乳様洞を開放しアヂッス側壁を幅広く且つ薄く残置 し， vertikale Brücke の作製を行ない乍ら上鼓室を開 放する．この際手術操作により嫴膜に対して全く影響の 加わらないように留意しつ」 Brücke を残した。

更に耳管開口部から下钴室にかけて鼓室を開放した。 vertikale Brücke の上端及び下端は特に細く薄くし てすぐにこれを除去できるようにしておく。

外耳道の皮膚は，高原 (嗞)の sliding down method 14）に従つて剝離，切開を行ない22)，外耳道皮癌の前部， 上部及び後部が上方に㼑転できるようにしておく．

この皮膚弁を上方に篧転し，Brücke 及び vertikale Brück を支持掻とするよらにして皮弁をセメダインで 張りつけ，及上端は上鼓室天蓋に同様にして接着し，し かも鐙骨頭及び砧骨には触れないようにする（第3図 1).

以上の如く操作したものについて実験を行なつたが， この点以外は，第 1 篇の場合と全く同様の実験方法を用 いた。

次に垁験成績を，操作を加えた順に従つて述ぺる。

1）以上操作を加えた側頭骨に，更に外耳道皮膚弁を vertikale Brücke を越えて乳様洞腔を保つよ5に乳様 洞骨壁に接着したものに対し，250,500，1000 及び 2000 cps の周波数を使用して音刺㦸を与え，その際の鐙骨板 の振幅を測定しこれを基準とした。

次に乳様洞を粘土によつて閉塞し，同様に測定を行な い，前者を基淮として Odb にとり後者の伝音能力の損

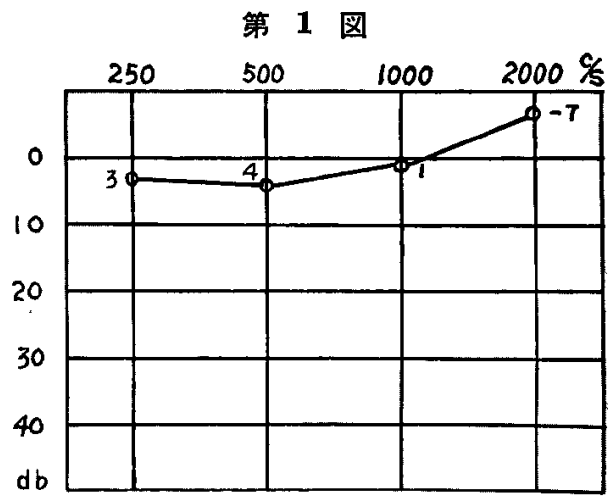


失をオージオグラムにあらいすと，第 1 図の如くで，乳 様洞を閉塞した場合，1000 cps 以下の低音部では伝音能 カが低下したが，2000cps では上昇を見た。

2）次に眽転して接着してある外耳道弁を剝離し， vertikale Brücke を除去した上, 寒天を 2 3\% に溶解 して上㒘室腔に注入し，これによつて楻骨頭部及び砧骨 に軽度の運動制限をきたすようにして，この上に外耳道 并を置いた場合の伝音能力を則定した。無験 1 亿おいて 基準にとつた測定值を Odb としてオーヂオグラムで示 すと.第2図の如くであつた：

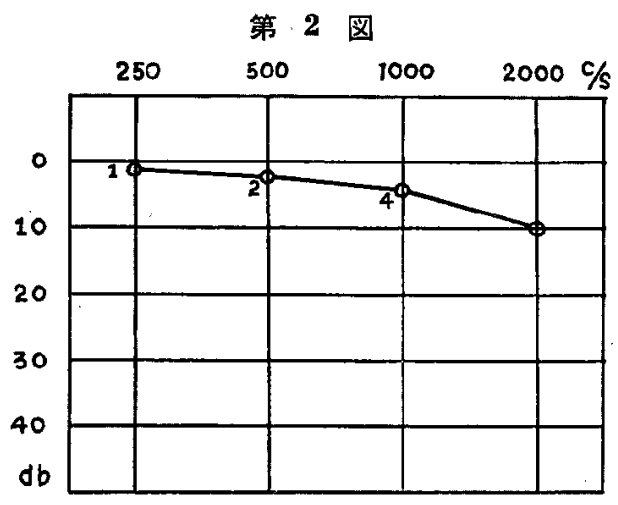

1.

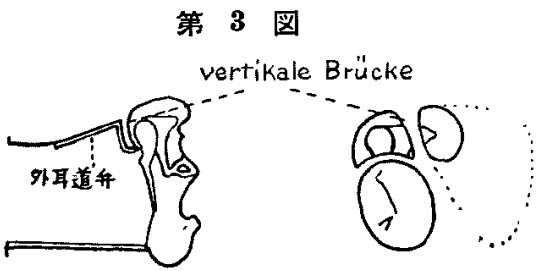

2.

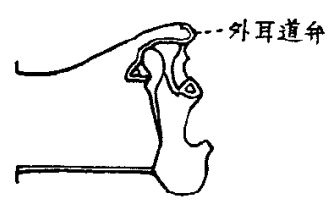

3）次に寒天を除去し，外耳道弁にビオゲラチンを塗 布してこの皮升が桘骨頭及び砧骨と強く癒着するように した場合（第3図2）恃同様にしてオーヂオグラムで示 すと、第4 图の様な伝音嵒失を示した。

上鼓室に寒天を注入した場合も，この晹合もいずれも mass curve ${ }^{16)}$ に似た傾斜を示した。
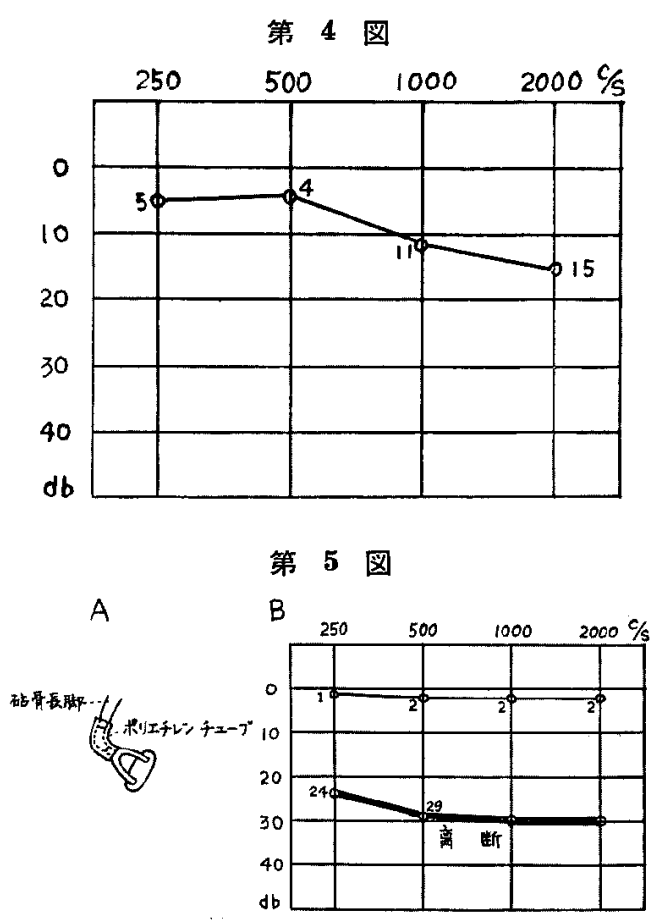

4)次に外耳道弁を再び遊離の状態にした後，桘骨頭 及び砧骨に影響のないように上鼓室を覆い，この際は人 屋体側頭骨を裹面から操作しているので，耳管開口部の 辺りから小剪刀を插入して砧鐙関節を離せ乙め，更に砧 骨の長脚先端を約 $1 \mathrm{~mm}$ 切断し，この断端と鐙骨頭を ポリェチレンチューブで接続した（第 5 図 $\mathrm{A}$ ).

砧鐙関節離断時の伝音能力の 損失は第 5 図 B のオー デオグラムの太線で示し，ポリエチレンチューブでこの 離断を修復した時の伝音能力を第 5 図 B の細線で示す。

離断修復時の伝音能力は著しく快復した。

\section{3. 総括及び考按}

笑験 1) では第 1 四に示したように，乳様洞を粘土充 填で閉塞乙場た合 1000,500 及び 250 cps において伝音 能力が約 $5 \mathrm{db}$ 低下した。恩地 ${ }^{10)}$ は正常耳の状態では 乳様洞の烲気容積の存在に上つて $1000 \mathrm{cps}$ 以下の周波 数に打いて約 $5 \mathrm{db}$ 内外耳の感度が增加し，1000 cps 以 上では感度が低下してくる事も認めて乱り，この原因を 乳様洞及び䗋巣が与员る踥膜インビーダンスの増加に帰 している．著者の実験 1 は恩地の説く所と正区対の実験 条件であるが，乳様洞を開塞して約 $5 \mathrm{db} の 1000 \mathrm{cps}$ 以 下の低音部に㧍ける伝音能力の低下，並びに䄪 $5 \mathrm{db}$ の 2000 cps における伝音能力の增加を認好て括り，この 
$5 \mathrm{db}$ の值は大体恩地の所説と一致している。

普通の鼓室成形術においては，乳椂洞及び蜂单は外耳 道と一つの腔を作り，鼓室とのつながりは消失するか ら，乳様洞が伝音能少に関与すると云与因子功失なわれ る.この事によつて $1000 \mathrm{cps}$ 以上では約 $5 \mathrm{db}$ 程度の聴 力の利得があり， $1000 \mathrm{cps}$ 以下では約 $5 \mathrm{db}$ 程度の聴力 の拱失が術後に見られるのではないかと推定される。

奜筷 2) ではアヂッス側壁を垂值位置に，又 Brücke を残して植皮弁の支持枠とする大内の meatoplastische Methode の伝音能力に及ぽす影響を検討した。即ら Brücke を除去して椎骨及び佔骨を覆うように植皮を行 つた場合は，術後桘骨及び砧骨々植皮贲の间に嘴着をき たして 伀音障碍を著起する場合があると考古られるの で，その揚合の程度の軽いものとして上鼓室に寒天を注 入し，㕛去の程度の強い場合として外耳道皮膚弁にピオ ゲラチンを塗布して桘砧骨と強く接着した．これらの伝 音障碍時には会話音域に特いて平均 2 乃至 $7 \mathrm{db}$ 程度の 伝音損失が見られ，著者の実験によれば，2000cps に拉 いて10 乃至 15db の低下が見られた事から 1000cps 以 上では低音域に和けるよりる更に高度の伝音能力の低下 が見られる事が想定される．従つて裁室成形術に括いて は Brücke あるいは vertikale Brücke 将㕛更になん らかの良法によつて上教室に和ける耳小骨速鎖の可陲性 に障碍を及ぼさないよらな注意を払ら必要があると考光 られる.

次に多くの慢性中耳炎に扣いて砧鐙関節の離断例が見 られ，この場合の伝音系修復力法には種々の考按が行な われている7、ポリエチレンチユーブあるいは tantarum wire を使用して離断部断端間を速結する方法は簡単で あるのでしばしば用はられる力法であるがて，実験 4 に よつてこの修復方法によつて修復され伝音系は非常に良 好な，殆んど正常に近い伝音能力を有している尋を嵲つ た。

砧鐙関節離断時 の伝音能力の損失は $30 \mathrm{db}$ 以内K止 つたが，この先験では音刺㦸に刘する鐙骨板の振動を゙测 定する方法によつたので, 中耳㐾音系としての正闷空の 要素を顧慮していない：この值は鼔膜及び耳小骨速鎖の 槙杆作用による卵円突八の音区堌強作用のない锡合の恥 力損失の計算 7)よりもや〉大きいが，これは䠣膜及び 櫝杆作用のない耳小骨によつて卵円䓗に達する音圧が減 弱された事によるものであらう。

鼓室成形術において，耳小骨連鎖の機能々のま あるいはこれに代る傮秀な修復伝音器を作る鸟ができる
としても，正常鼓膜と同様の能力をもつ新生影膜を得る

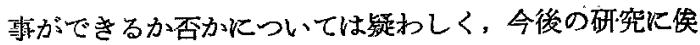
つ所が多いが，むしポリエチレンチーブが生体に対し長 期にわたつて異物として作用をあらわす事がないとする ならば，ポリエチレーンチュープ法は砧鐙関節離断時の 一伝音系修復方法として試みるべき良法であると考えら れる。

\section{4. 結 語}

人の剔出側頭骨について，鼓空成形術に和ける琵々の 伝音系を实験的に作り，夫々の伝音能力を湘定し，次の 結果を得た。

1）乳様洞の 空気容積の 存在は $1000 \mathrm{cps}$ 以下で約 5 $\mathrm{db}, 2000 \mathrm{cps}$ で約 $-5 \mathrm{db}$ の聴力增進をきたす機能を有 する。

2）上㩆室において，皮弁と桘骨頡及び桘骨との間に 洨着があると，1000 cps 以上で特汇著しい伝音損失があ る(2000cps では10 フ5至 15db).

3) Brücke あるいは vertikale Brücke によつて植 皮弁の支持枠を作るような方法をとる事が伝音能力を良 好に保つ上に望ましい。

4) 砧鐙関節の離断時には鐙骨板の振動は正常伝音系 の場合に比して約 30db 伝音能力の低下があつた.

5）砧鐙関節の離断時に，ポリエチレンチューブで離 断を修復した場合，極く僅かっ后音損失が見られてた止 まつた。

\section{文献}

1) Zöllner, F.: The principles of plastic surgery of the souud conducting apparatus. J. Laryng. \& Otol., 69: 637, 1955. 2) Wever, E.G. \& Lawrence, M.: Physiological Acoustics, 1954. 3) Békésy, G.V.: Experiments in hearing, 1960. 4) Dahmann, $H$.: Zur Physiologie des Hörens; Experimentelle Untersuchungen über die Mechanik der Gehörknöchenkette, sowie über denen Verhalten auf Ton und Luftdruck. Arch. Ohren-usw. Heilk., 24: 462, 1929. 5) Wullstein, H.: Theory and Practice of Tympanoplasty. Laryngoscope, 66: 1076, 1956. 6) Juers, $M$. Preservaticn of hearing in surgery for chronic ear diseases. Laryngoscope, 68: 825, 1958.47 ) Shambaugh, Jr., G.E.: Surgery of the Ear, 1960. 8) Perlman, H.B.: Some physical properties of the condnction apparatus. Ann. of Oto-Rhino. \& Laryng., 56:334, 1947. 9) 切替一郎：伝音機棈々骨導に関 
する基礎的研究，日耳鼻 58 回宿題報告，昭 32 .

10) 恩地豊：聴器の云音機桡，日耳舜 61 回宿題報告，昭 35. 11) Schmitt, H.: Über die Bedeutung der Schalldrucktransformation und der Schallprotektion für die Hörschwelle, Acta Oto-laryng., 49 : 71, 1958. 12) 土田登：豉空成形術の実験的研㶢, 日耳與 62 巻, 2199, 昭 34. 13) Kobrak, H.G.: The Middle Ear. 1959. 14) 高原泫夫： Sliding down method と羅

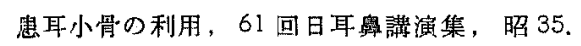
Beranek, L.L.: Acoustics, 1954. 16) Johanson, $H$.: Relation of audiograms to the impedance formula. Acta Oto-Laryng., Supp. 74: 65, 1948. 17) Hjorth, S., Lundborg, T. \& Rösler, G.: Zum Schalleitungsmechanismus des Mittelohrs, Acta OtoLaryng., 50: 423, 1959. 18) Wullstein, H.: Prognose und Resultat der Tympanoplastik, Acta Oto-Laryng., 45:460, 1955 . 19) Shuknecht, H,F. E Oleksiuk, S.: Tympanoplasty. Laryngoscope, 69: 614, 1959. 20) Bruner, M.: Erhaltung u. Resta- urierung des Gehörgạnges bei Tympanoptatiken. Zschr. Laryng. usw . 93:1, 1959.21 ) 大内仁: 我が教室に扣ける鼓室成形術 (2) “meatoplastische Methode”について，耳喉科，32㷀；975，昭 35 .

22）高原滋夫：耳畄咽喉科最近の進步，394, 1950,

23) 操坦道, 他：医学エレクトロニクス。

稿を終るに当り，終始御烈篤なる御指脊と御 校閲を賜つた恩師高原滋夫教授に深甚なる謝意 を表すると共に，䅂始御協力，御得擭を頂いた 黒住助教授, 頼実講師, 瀬崎技士ならびに教室 員諸兄に衰心より感謝致します

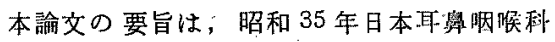
学会第 81 回中国地方会，第5 回オーヂオロギ 一学会及び第 493 回岡山医学会例会机和いて誼 速した。

（原唃到着=昭和 36.3 .27 日） 